\begin{tabular}{|c|c|c|}
\hline & International Journal of Current Research in & \\
\hline & Biosciences and Plant Biology & 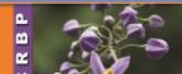 \\
\hline $\begin{array}{ll}\text { EXCl } \\
\text { PUBI }\end{array}$ & 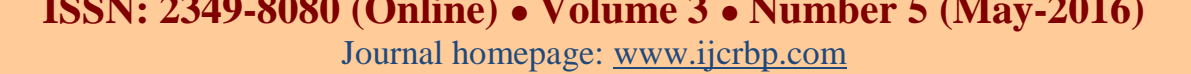 & \\
\hline
\end{tabular}

\title{
An Attempt to Overcome Dioxane Toxicity by Rabbits using Vitamin C
}

\author{
A. M. Abdelhamid*, Rehab F.S. A. Ismael and Manar A. Almnsy \\ Animal Production Department, Faculty of Agriculture, Al-Mansourah University, Egypt \\ *Corresponding author.
}

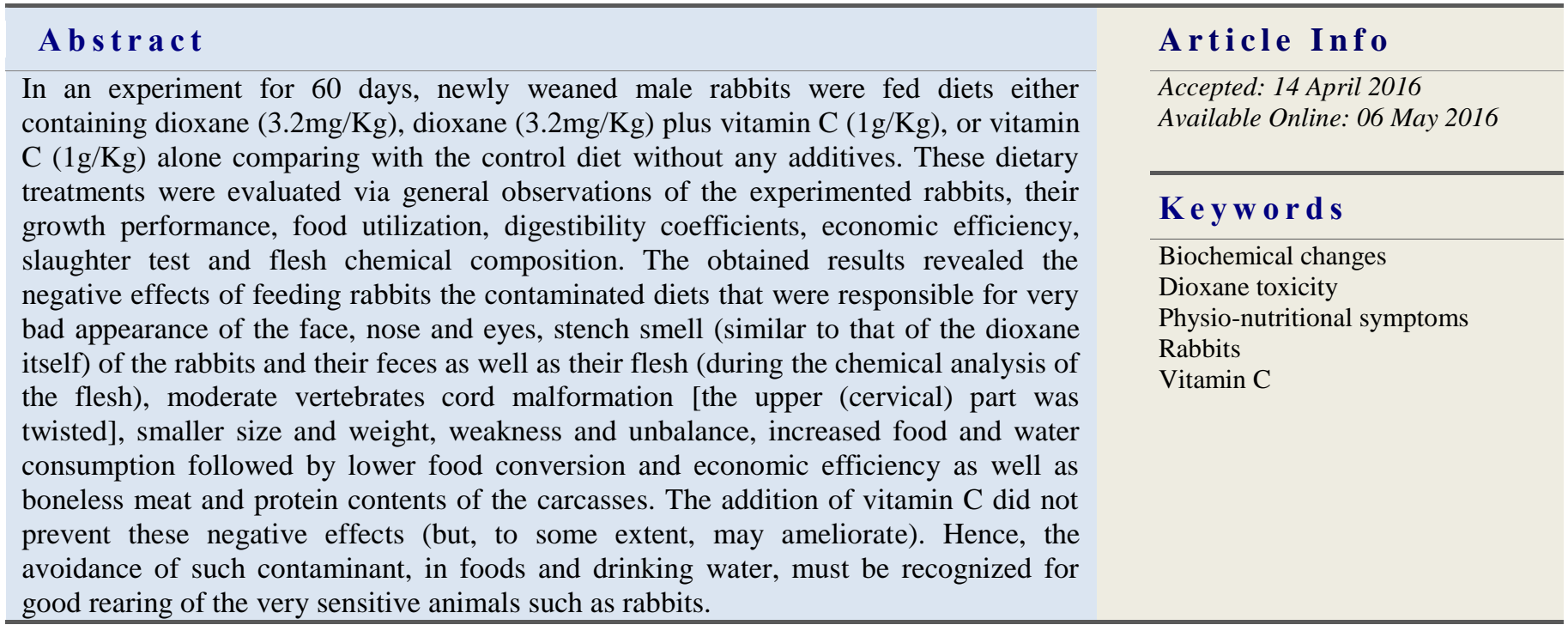

\section{Introduction}

From the related compounds to dioxins is the 1,4dioxane. The 1,4-dioxane is detected in soil (Barone et al., 1992), air (Brown et al., 1994), water (Yasuhara et al., 2003), aquatic life (Kasai et al., 2009) and some cosmetics. Exposure to 1,4-dioxane may cause damage to the central nervous system, liver and kidneys (ICSC, 2006). Under Proposition 65, dioxane is classified in the U.S. State of California to cause cancer (Hazard Summary, 2000). It is also classified by the IARC as a Group 2B carcinogen: possibly carcinogenic to humans because it is a known carcinogen in other animals. Dioxane is classified by the National Toxicology Program as "reasonably anticipated to be a human carcinogen" (OPPT, 2014). The 1,4-dioxane could be bioconcentrated in aquatic organisms (Franke et al.,
1994), since 1,4-dioxane is very slow to biodegrade (Kelley et al., 2001). Accidental exposure to dioxin was reported in Belgian chicken feed (De Vries et al., 2006), Czech guar gum (CAFIA, 2008), Ireland's feeds (UKFSA, 2008), food and feed (EFSA, 2010), German eggs (Radio Hamburg, 2011). This demonstrates that European animal feed industry fails to follow basic safety rules (NDR, 2011). So, the consultation concerning health risk of dioxins in May 1998, Geneva re-evaluated the upper range of the total daily intake of 4 pg TEQ/kg bodyweight should be considered a maximal tolerable intake on a provisional basis and that the ultimate goal is to reduce human intake levels below $1 \mathrm{pg}$ $\mathrm{TEQ} / \mathrm{kg}$ bodyweight/day. In Germany, the human exposure is supposed to be only $45 \%$ of the limit of $1 \mathrm{pg}$ $\mathrm{TEQ} / \mathrm{kg}$ bodyweight/day. However, low levels of dioxin from environment are present in vegetables and all other 
kind of foods (OEHHA, 2007). A few cases of intentional human poisoning have also been reported. The most notable incident is the 2004 case of Viktor Yushchenko, President of the Ukraine, whose face was disfigured by chloracne (Schecter and Gasiewicz, 2004 and Allen, 2010). So, the aim of the present work was to evaluate the effect of low level of 1,4-Dioxane on rabbits' performance, as well as its biochemical, physionutritional and histological aspects and if vitamin $\mathrm{C}$ could overcome dioxane toxicity symptoms.

\section{Materials and methods}

An indoor experimental study was carried out in a private farm for two months from the $15^{\text {th }}$ of December 2015 till the $14^{\text {th }}$ of February 2016 (after an adaptation period of 4 days on the experimental farm conditions, from 11 to 14 December 2015) with the cooperation of The Department of Animal Production, Faculty of Agriculture, AlMansourah University to evaluate the dietary inclusion of 1,4-dioxane and/or vitamin $\mathrm{C}$ in the diet of Flan rabbits.

\section{Experimental animals}

Twenty four V-line male rabbits newly weaned, 25 day old and weighing in average $450 \mathrm{~g}$ were purchased from the Experimental Station (at Sekinah village) belonging to Saba Basha Faculty of Agriculture, Alexandria University. After their transportation to the experimental farm, they adapted for the experimental farm conditions for 4 days. Thereafter were divided randomly onto the housing wire batteries (each of one horizontal floor contains 6 cages or boxes, $2 \times 0.5 \times 1.2 \mathrm{~m}$ ) supplied with drinkers, feeders, heater, thermometer and hygrometer to measure temperature and relative humidity of the surrounding air, at 2 rabbits / cage or box $(50 \times 30 \times 33.4 \mathrm{~cm}), 3$ replicates / treatment $(=2 \times 3=6$ rabbits / treatment). Four experimental treatments, i.e., groups, were tested as follows:

- Treatment 1 (T1) or group 1' animals were fed a commercial (control) diet (negative control) as given.

- Treatment 2 (T2) or group 2' animals were fed the same commercial (control) diet plus 1,4-dioxane (toxic diet) at level of $3.2 \mathrm{mg} / \mathrm{Kg}$ diet (3.2 ppm).

- Treatment 3 (T3) or group 3' animals were fed the same commercial (control) diet plus 1,4-dioxane at level of 3.2 $\mathrm{mg} / \mathrm{Kg}$ diet (3.2 ppm)plus vitamin $\mathrm{C}$ at level of $1 \mathrm{~g} / \mathrm{Kg}$ diet (treated diet).

- Treatment 4 (T4) or group 4' animals were fed the same commercial (control) diet plus vitamin $\mathrm{C}$ at level of $1 \mathrm{~g} / \mathrm{Kg}$ diet (positive control).

\section{Experimental diets preparation}

The commercial diet (control) was purchased from ALMASRIAH Factory of Feed Manufacture at BanyAamer, Zagazig, Sharqia Governorate. The control pellets were 1.5-2.0 cm length, $3.5 \mathrm{~mm}$ diameter, and colored light green. This commercial (control) diet contents of the following ingredients: $15 \%$ soya meal (44\% crude protein), $10 \%$ yellow maize, $30 \%$ wheat bran, $16 \%$ barley, $20 \%$ lucerne meal, $5.4 \%$ medical herbs straws and seeds, $0.05 \%$ anti-coccidian, $0.05 \%$ antitoxins, $40 \mathrm{~g}$ digestive enzymes, $0.03 \%$ fattening premix, $0.04 \%$ minerals, $1.5 \%$ lime stone, $0.05 \%$ L-methionine, $0.05 \%$ L-lysine, $0.7 \%$ dicalcium phosphate, $0.3 \%$ common salt, and $0.16 \%$ sodium bicarbonate. The chemical analysis of this diet (as given by the manufacturer) is not more than $19 \%$ crude protein (CP), not more than $2.2-2.5 \%$ crude fibers, not less than $15-$ $16 \%$ crude fats, $32 \%$ starch, and not less than 2300 $2500 \mathrm{Kcal}$. metabolizable energy. But when its chemical composition was calculated according to NRC (2005), it has $17.92 \% \mathrm{CP}$ and $2487 \mathrm{Kcal}$. digestible energy. The daily actual feed and water consumptions were calculated.

The control diet (from ALMASRIAH Factory of Feed Manufacture) was mechanically flanked to add the experimental additives (1,4-dioxane and vitamin C), thereafter repressed and repelleted in Albashbishy Factory in Tanta. Vitamin C used in this study was Asco-Vet C $20 \%$ (powder), valid for 2 years from date of manufacture (5/2015), Batch No. 716, produced by Selim Pharm. for Eng. A.ElalimWakid, Registration No. 1968 (ElFath for Trading and Distribution, FTD, Web: www.elfath-ftd.com, E-mail: Info@elfath-ftd.com). It was added to the ingredients of the control diet and the control diet plus dioxane at concentration of $1 \mathrm{~g} / \mathrm{Kg}$ diet to form diets No. 4 and 3, respectively. To add the vitamin $\mathrm{C}$ to the diets, $250 \mathrm{~g}$ of the vitamin powder (20\%) were dissolved in $500 \mathrm{ml}$ water, then were sprayed on the $50 \mathrm{Kg}$ ground control pellets to obtain a concentration of $1 \mathrm{~g}$ vitamin $\mathrm{C} / \mathrm{Kg}$ food. The food mixture was then repressed and repelleted at $45^{\circ} \mathrm{C}$ (to protect the vitamin $\mathrm{C}$ from decomposition) to $1 \mathrm{~cm}$ length and $3 \mathrm{~mm}$ diameter.

The liquid form of 1,4 dioxane (M.W. 88.11, Mfg. Dt.: Jan. 2014, Exp. Dt.: Dec. 2018, Batch No. 1268, Code No. D-03532, CAS, No. 123-91-1, Assay: Min. 98\%, For Lab. Use only, Made in India, Oxford Laboratory Reagent ISO: 9001-2008, Website: www.oxfordlabchem.com, E-mail: oxfordchemlab@yahoo.co.in) was used. It was diluted in 
water to enable spraying small volume on the ingredients of the toxic diet No. 2 and toxic diet plus vitamin C (diet No. 3). To prepare the dioxane containing diets, ten liters of water were mixed with $5 \mathrm{ml}$ dioxane, then $320 \mathrm{ml}$ of this mixture ware taken and sprayed on the ground-fifty $\mathrm{Kg}$ of the control diet during mixing to be sure that the small volume of dioxane was good homogenized; thereafter, the toxic-food mixture was repressed and repelleted (at $45^{\circ} \mathrm{C}$ to protect the dioxane from decomposition) to $1 \mathrm{~cm}$ length and $3 \mathrm{~mm}$ diameter.

\section{Daily observations and management}

Daily observations were inspected besides weighing the rabbits, food and drinking water. Photos and X-ray (Dr. H. A. Mohamed's Center for Diagnostic Ray, Tanah, Dakahlia Governorate) were also taken for the experimental rabbits.

\section{Digestibility trials}

At the last 5 days of the fattening experiment (as a collection period), three animals / treatment were randomly taken and separately housed in the same batteries. Daily feed consumption and feces excreted were weighed, collective samples (from the food and the feces) were taken and kept in a refrigerator at $-4^{\circ} \mathrm{C}$ till the chemical analysis (for moisture, ash, crude protein, ether extract and crude fiber according to AOAC (1990) in the second day (by the chemical analysis laboratory of Factory of Oils and Soap, at Sandop, Al-Mansoura) to calculate the digestibility of different nutrients.

\section{Slaughter test}

At the end of the digestibility trials, the same 3 animals/treatment were fasted for $12 \mathrm{hrs}$, slaughtered, de-headed, de-skinned, eviscerated, the carcass was divided into different parts and each organ and / or parts was weighed individually. Thereafter, the flesh was fillet and the dressing and boneless meat percentages were calculated.

\section{Carcass analysis}

Representative samples (from the four legs and back of each the three rabbits / treatment of the digestibility trials and slaughter test) were collected together and minced, then kept frozen at $-20^{\circ} \mathrm{C}$ for a night, thereafter directly send for chemical analysis by the laboratory of Factory of Oils and Soap, at Sandop, Al-Mansoura according to AOAC (1990).

\section{Statistical analysis}

The obtained numerical data were statistically analyzed using standard error (SE), coefficient of variance (CV $\%$ ), and t-test according to Sachs (1976), where SE = standard error of the sample (S) / $\sqrt{ } \mathrm{n}, \mathrm{CV} \%=100[\mathrm{~S} /$ mean $(\mathrm{X})]$, and $\mathrm{t}=\left(\mathrm{X}_{1}-\mathrm{X}_{2}\right) /\left[\sqrt{ }\left(\mathrm{S}_{1}{ }^{2} / \mathrm{n}_{1}\right)+\left(\mathrm{S}_{2}{ }^{2} / \mathrm{n}_{2}\right)\right]$.

\section{Results}

\section{General observations}

Air temperature $\left({ }^{\circ} \mathrm{C}\right)$ and relative humidity (\%) surrounding the experimental rabbits' batteries were recorded 4 times daily ( $7 \mathrm{am}, 1 \mathrm{pm}, 5 \mathrm{pm}$, and $11 \mathrm{pm}$ ) for the 60-day experimental period. The temperature and relative humidity were constant throughout the experimental period, being $18-21^{\circ} \mathrm{C}$ and $68-72 \%$.

The experimented rabbits seem healthy, except the rabbits of the dioxane-group that appear weak, one of them appeared unpleasant, with very bad injured face from the $10^{\text {th }}$ day of the experimental feeding $(25 / 12 / 2015)$, i.e., after ingestion of about $850 \mathrm{~g}$ toxic diet contained $2.82 \mathrm{mg}$ dioxane. These injuries were increased by time. This case was appeared on the mouth, nose, face, and eyes; with wet-dirty hair of the face (may be due to increased saliva secretion). This rabbit was unbalanced, reflecting perhaps nervous and muscular dysfunctions. New hair coat was grown on the face from the $1^{\text {st }}$ of February 2016.

The rabbits fed the toxic diet + vitamin $\mathrm{C}$ seemed normal but weighed lighter than those fed either control or control + vitamin $\mathrm{C}$ diets. That means that Vitamin $\mathrm{C}$ inclusion may reduce the toxic effect of dioxane-included diet. Rabbits fed vitamin C supplemented diet were moved naturally, weighed similar to the control rabbits but heavier than those fed dioxane-containing diets, whether with or without vitamin $\mathrm{C}$. The control rabbits seem larger than those fed the control diet plus vitamin $\mathrm{C}$ or those fed the control diet plus dioxane plus vitamin $\mathrm{C}$ or those fed the control diet plus dioxane. Yet, the control rabbits weighed similar to the rabbits fed the control diet plus vitamin $\mathrm{C}$ (both groups of animals had good appetite to food), but weighed heavier than those fed the dioxane-containing diets (their animals has less appetite to food). The hair coat of the rabbits fed the control diet plus vitamin $\mathrm{C}$ was smooth and bright, whereas the animals of the other treatments had scattered hair. 
The X-ray tacking after one month of the experimentbegin for the experimental rabbits clears that dioxanetreated rabbits were smaller sizes than all other treatments, with severe spinal cord malformation. Whereas vitamin $\mathrm{C}$ reduced the negative effect of dioxane although the moderate vertebrates cord malformation (the upper (cervical) part was twisted); yet, the control rabbits were better than those fed dioxane + vitamin C. However, the dietary supplementation with vitamin $\mathrm{C}$ only gave sound rabbits with better appearance, growth and size.

After two months of the feeding experiment (on the 30th of January 2016), (i.e., after ingestion of about $7325 \mathrm{~g}$ diet contained $32.44 \mathrm{mg}$ dioxane and $7.325 \mathrm{~g}$ vitamin $\mathrm{C}$ ) one rabbit of the treatment fed dioxane plus vitamin $\mathrm{C}$ showed weakness of the leg and neck muscles and severe vertebrate cord malformation (the upper (cervical) part was twisted towards the left side). That means that dietary inclusion of vitamin $\mathrm{C}$ had delayed (but not hidden) the toxic effect of dioxane on the vertebrate cord deformation (which had occurred in dioxane-only fed rabbits after one month of toxic feeding).

On the $20^{\text {th }}$ of January 2016, two rabbits of the treatment group fed control plus vitamin C suffered (for three days) from food refusal, weakness, scattered hair, severe bloat, very bad-smell green-diarrhea, and on the $22^{\text {nd }}$ of January 2016 suffered from abdominal edema then dead on the $23^{\text {rd }}$ of January 2016. Their post-mortem examination reflected stink-smell green-liquid in the abdominal cavity, filled stomach and intestine with liquids, internal bleeding, congestion, red-white lungs, enlarged gall bladder, and atrophied congested liver.
The control rabbits excreted small sized feces particles than that of rabbits fed control diet plus vitamin $\mathrm{C}$. The control rabbits' feces is adhesive, irregular in shape, unacceptable in smell, dark black colored, mixed with urine and scattered feed. Rabbits fed the dioxane-only containing diet excreted irregularly, soft, connected together, dark-black colored and bad-smell feces. Rabbits fed dioxane + vitamin $\mathrm{C}$ gave light-black colored feces with separate particles. Whereas, vitamin $\mathrm{C}$ only fed rabbits had yellowish-black colored feces with circular contact particles.

\section{Chemical analysis of the experimental diet}

The following Table 1 presents the chemical analysis of the experimental diet, which was carried out by the Dakahlia Co. for Poultry, Al-Enany, Damas, Dakahlia governorate.

Table 1. Proximate chemical analysis of the tested diet.

\begin{tabular}{ll}
\hline Nutrients & Composition, \% \\
\hline Moisture & 10.89 \\
Protein, CP & 15.79 \\
Fat, EE & 2.725 \\
Starch & 30.75 \\
Crude fiber, CF & 11.03 \\
Ash & 7.160 \\
\hline
\end{tabular}

\section{Growth performance}

Although all parameters calculated herein did not significantly differ among treatments (Table 2); yet, the mean-values of FLBW, TBWG and ADG of the dioxane group (T2) were markedly lower than those of the control group (T1).

Table 2: Mean* \pm standard error (and coefficient of variance, \%) of initial live bodyweight (ILBW, g/rabbit), final live bodyweight (FLBW, g/rabbit), total bodyweight gain (TBWG, g/rabbit), and average daily gain (ADG, g/rabbit) of different treatments' rabbits throughout the entire experimental period (60 days).

\begin{tabular}{lllll}
\hline Items & $\begin{array}{l}\text { Control } \\
\text { (T1) }\end{array}$ & $\begin{array}{l}\text { Dioxane } \\
\text { (T2) }\end{array}$ & $\begin{array}{l}\text { Dioxane + Vitamin C } \\
\text { (T3) }\end{array}$ & $\begin{array}{l}\text { Vitamin C } \\
\text { (T4) }\end{array}$ \\
\hline ILBW & $525.8 \pm 6.11(2.85)$ & $497.5 \pm 12.0(5.89)$ & $505.0 \pm 13.4(6.48$ & $545.0 \pm 5.00(2.25)$ \\
FLBW & $1705 \pm 48.5(6.96)$ & $1452 \pm 121.9(20.6)$ & $1611 \pm 48.8(7.42)$ & $1480 \pm 179.8(24.3)$ \\
TBWG & $1203 \pm 38.5(7.84)$ & $954.5 \pm 111.7(28.7)$ & $1106 \pm 58.7(13.0)$ & $929.5 \pm 179.8(38.7)$ \\
ADG & $20.8 \pm 2.95(34.8)$ & $15.9 \pm 1.86(28.6)$ & $18.4 \pm 0.98(13.0)$ & $15.4 \pm 2.99(38.9)$ \\
\hline
\end{tabular}

*: Each value is the mean of 6 rabbits, except that of $\mathrm{T} 3(\mathrm{n}=4$ for the death of 2 rabbits).

\section{Food utilization}

The following Table 3 presents mean values of 6 rabbits/treatment (except that of $\mathrm{T} 3$ where $\mathrm{n}=4$ for the death of 2 rabbits) for food and water consumption, food conversion ratio, and economic efficiency. There were significant differences ( $p \leq 0.001$ or 0.01 ) between both treatments $\mathrm{T} 1$ and $\mathrm{T} 2$ in all calculated parameters in favor of the control group (T1). That means that rabbits fed the toxic diet (T2) consumed significantly the highest food and water $(p \leq 0.001)$, but converted this food to meat at lowest $(p \leq 0.01)$ comparing with the other 
treatments. The economic efficiency (expressed as percentage of food cost from the cost of the live bodyweight gain) also was the worst for T2 (toxic diet) comparing with the other treatments. Yet, the dietary inclusion of vitamin $\mathrm{C}$ (T3) reduced these negative effects of dioxane on these criteria.

Table 3. Mean* \pm standard error (and coefficient of variance, $\%$ ) of average daily (ADFI, g/rabbit) and total food intake (TFI, $\mathrm{g} /$ rabbit) and average daily (ADWC, ml/rabbit) and total water consumption (TWC, ml/rabbit), food conversion ratio (FCR), and economic efficiency (EE, \%) of different treatments' rabbits throughout the entire experimental period (60 days).

\begin{tabular}{lllll}
\hline Items & $\begin{array}{l}\text { Control } \\
(\mathbf{T} 1)\end{array}$ & $\begin{array}{l}\text { Dioxane } \\
(\mathbf{T} 2)\end{array}$ & $\begin{array}{l}\text { Dioxane+Vitamin C } \\
(\mathbf{T 3})\end{array}$ & $\begin{array}{l}\text { Vitamin C } \\
(\mathbf{T} 4)\end{array}$ \\
\hline ADFI & $102.4^{\mathrm{B}} \pm 9.46(2.26)$ & $126.0^{\mathrm{A}} \pm 3.06(5.95)$ & $122.1^{\mathrm{ACD}} \pm 0.64(1.28)$ & $127.3^{\mathrm{AC}} \pm 2.27(3.57)$ \\
TFI & $6150^{\mathrm{B}} \pm 57.5(2.29)$ & $7564^{\mathrm{A}} \pm 183.8(5.95)$ & $7325^{\mathrm{ACD}} \pm 38.5(1.29)$ & $7639^{\mathrm{AC}} \pm 136.8(358)$ \\
ADWC & $252.2^{\mathrm{B}} \pm 4.94(4.80)$ & $303.7^{\mathrm{A}} \pm 0.84(0.68)$ & $281.2^{\mathrm{D}} \pm 1.83(1.59)$ & $261.3^{\mathrm{BC}} \pm 2.17(1.66)$ \\
TWC & $15134^{\mathrm{B}} \pm 296.5(4.80)$ & $18221^{\mathrm{A}} \pm 50.2(0.67)$ & $16875^{\mathrm{D}} \pm 109.5(1.59)$ & $15675^{\mathrm{BC}} \pm 129.9(1.66)$ \\
FCR & $5.12^{\mathrm{b}} \pm 0.17(8.18)$ & $8.47^{\mathrm{a}} \pm 1.00(28.8)$ & $6.68^{\mathrm{C}} \pm 0.37(13.6)$ & $9.79^{\mathrm{ab}} \pm 2.75(56.2)$ \\
EE & $63.4^{\mathrm{b}} \pm 2.09(8.09)$ & $104.8^{\mathrm{aA}} \pm 12.3(28.6)$ & $83.0^{\mathrm{cB}} \pm 4.56(13.5)$ & $70.5^{\mathrm{abc}} \pm 17.2(48.7)$ \\
\hline
\end{tabular}

*: Each value is the mean of 6 rabbits, except that of T3 ( $\mathrm{n}=4$ for the death of 2 rabbits). A-D and a-c: means in the same row superscripted with different capital or small letters differ significantly at $p \leq 0.001$ or 0.01 , respectively.

The following Table 4 presents digestibility coefficient of different dietary nutrients of the tested rations for different rabbits' groups at the end of the feeding trial $(60$ days). It is clear that the only significant $(p \leq 0.05)$ differences among rabbits' groups were calculated between $\mathrm{T} 1$ on one side and $\mathrm{T} 2$ and $\mathrm{T} 3$ on the other hand concerning crude protein digestibility; and between T1 and $\mathrm{T} 2$ for ether extract digestibility.

Table 4. Mean* \pm standard error (and coefficient of variance, $\%$ ) of digestibility coefficient (\%) of different dietary nutrients of the tested rations for different rabbits' groups at the end of the feeding trial (60 days).

\begin{tabular}{lllll}
\hline Items & $\begin{array}{l}\text { Control } \\
(\mathbf{T 1})\end{array}$ & $\begin{array}{l}\text { Dioxane } \\
\text { (T2) }\end{array}$ & $\begin{array}{l}\text { Dioxane+Vitamin C } \\
\text { (T3) }\end{array}$ & $\begin{array}{l}\text { Vitamin C } \\
\text { (T4) }\end{array}$ \\
\hline Organic matter & $61.2 \pm 4.23(12.0)$ & $60.1 \pm 1.22(3.51)$ & $62.1 \pm 1.91(5.33)$ & $62.3 \pm 2.53(7.03)$ \\
Crude protein & $40.4^{\mathrm{b}} \pm 3.38(14.5)$ & $56.6^{\mathrm{a}} \pm 2.01(6.16)$ & $56.2^{\mathrm{a}} \pm 5.64(8.15)$ & $46.1^{\mathrm{ab}} \pm 9.58(36.0)$ \\
Ether extract & $85.8^{\mathrm{a}} \pm 1.22(2.46)$ & $79.1^{\mathrm{b}} \pm 1.92(4.20)$ & $44.0^{\mathrm{ab}} \pm 21.7(85.3)$ & $78.9^{\mathrm{ab}} \pm 6.82(15.0)$ \\
\hline
\end{tabular}

*: Each value is the mean of 3 rabbits, a-c: means in the same row superscripted with different letters differ significantly at $p \leq 0.05$.

Table 5. Mean* \pm standard error (and coefficient of variance, \%) of percentages (from live bodyweight) different parts of different treatments' rabbits at the end of the entire experimental period (60 days).

\begin{tabular}{lllll}
\hline Items & $\begin{array}{l}\text { Control } \\
\text { (T1) }\end{array}$ & $\begin{array}{l}\text { Dioxane } \\
\text { (T2) }\end{array}$ & $\begin{array}{l}\text { Dioxane+Vitamin C } \\
\text { (T3) }\end{array}$ & $\begin{array}{l}\text { Vitamin C } \\
\text { (T4) }\end{array}$ \\
\hline Skin, feet, tail, ear, and head skin & $15.2 \pm 0.99(11.2)$ & $15.2 \pm 0.31(3.56)$ & $14.4 \pm 0.69(8.12)$ & $15.3 \pm 0.59(6.63)$ \\
Deskined head & $8.73 \pm 3.04(60.2)$ & $6.67 \pm 0.40(10.4)$ & $6.16 \pm 0.53(14.8)$ & $7.39 \pm 0.84(19.6)$ \\
Liver & $3.07 \pm 0.30(16.7)$ & $3.77 \pm 0.47(21.4)$ & $3.82 \pm 0.27(12.1)$ & $3.05 \pm 0.09(5.02)$ \\
Kidneys & $0.57 \pm 0.04(11.7)$ & $0.67 \pm 1.00(24.8)$ & $0.64 \pm 0.03(6.81)$ & $0.65 \pm 0.03(9.23)$ \\
Heart & $0.24 \pm 0.02(16.8)$ & $0.27 \pm 0.05(29.9)$ & $0.27 \pm 0.01(5.66)$ & $0.29 \pm 0.02(12.1)$ \\
Stomach, intestine and lungs & $21.4 \pm 1.45(11.8)$ & $24.2 \pm 0.42(15.7)$ & $21.3 \pm 1.31(10.7)$ & $24.0 \pm 0.72(5.21)$ \\
Right-front quarter & $9.02^{\mathrm{abAB}} \pm 0.27(5.15)$ & $8.89^{\mathrm{B}} \pm 0.14(2.70)$ & $9.46^{\mathrm{aA} \pm 0.08(1.45)}$ & $8.90^{\mathrm{bAB}} \pm 0.14(2.68)$ \\
Left-front quarter & $9.02^{\mathrm{abAB}} \pm 0.27(5.15)$ & $8.89^{\mathrm{B}} \pm 0.14(2.70)$ & $9.46^{\mathrm{aA}} \pm 0.08(1.45)$ & $8.90^{\mathrm{bAB}} \pm 0.14(2.68)$ \\
Right-hind quarter & $9.63 \pm 0.26(4.68)$ & $9.30 \pm 0.46(8.64)$ & $9.64 \pm 0.46(8.32)$ & $10.0 \pm 0.33(5.75)$ \\
Left-hind quarter & $9.63 \pm 0.26(4.68)$ & $9.30 \pm 0.46(8.64)$ & $9.64 \pm 0.46(8.32)$ & $10.0 \pm 0.33(5.75)$ \\
Dorsal muscle & $9.47 \pm 0.62(11.3)$ & $9.87 \pm 0.49(8.61)$ & $10.4 \pm 0.84(13.9)$ & $10.5 \pm 1.09(17.9)$ \\
Deskinned carcass & $78.1^{\mathrm{B}} \pm 0.77(1.71)$ & $82.9^{\mathrm{AB}} \pm 1.70(3.54)$ & $80.9^{\mathrm{AB}} \pm 3.75(8.03)$ & $84.7^{\mathrm{A}} \pm 0.59(1.21)$ \\
Eviscerated carcass (dressing) & $49.1 \pm 1.21(23.1)$ & $49.6 \pm 1.45(5.08)$ & $51.3 \pm 2.60(8.77)$ & $51.8 \pm 2.14(7.16)$ \\
Meat (boneless) & $36.0^{\mathrm{a}} \pm 1.77(8.52)$ & $28.5^{\mathrm{b}} \pm 2.08(12.6)$ & $30.5^{\mathrm{b}} \pm 0.79(4.48)$ & $32.0^{\mathrm{ab}} \pm 3.34(18.1)$ \\
Bone & $12.1 \pm 0.56(8.01)$ & $13.1 \pm 0.94(12.4)$ & $11.8 \pm 1.04(15.3)$ & $13.6 \pm 0.95(12.1)$ \\
\hline
\end{tabular}

*: each value is the mean of 3 rabbits/treatment. A-B and a-b: means in the same row superscripted with different capital or small letters differ significantly at $p \leq 0.01-0.001$ or 0.05 , respectively. 


\section{Slaughter test}

Table 5 shows the results of the slaughter test as the different parts percentage (from live bodyweight of the experimented rabbit) of the carcasses. The only significant differences were calculated for the front quarters, de-skinned carcass, and bones meat percentages, since dioxane (T2) had the lowest $(p \leq 0.001)$ front quarters and boneless meat $(p \leq 0.05)$ percentages. The addition of vitamin $\mathrm{C}$ to the toxic diet (T3) ameliorated the negative effect of dioxane alone in the diet on the edible parts of the rabbits' carcass. The dietary addition of vitamin $\mathrm{C}$ alone reflected higher dorsal muscle, eviscerated carcass, and boneless meat percentages.

Table 6 presents data of meat chemical composition of the rabbits' carcasses, the significant $(p \leq 0.01)$ alterations were calculated only among ash and crude fiber values; since flesh of rabbits' group T3 (dioxane + vitamin C) reflected the lowest ash content and the dioxane treatment (T2) gave the lowest crude fiber content. It is worth noting that during the dryness of the carcass meat of the dioxane-treated rabbits (whether fed dioxane only or dioxane plus vitamin $\mathrm{C}$ ), a very stink-smell was outspread (similar to that of the 1,4-dioxane itself).

Table 6. Mean* \pm standard error (and coefficient of variance, $\%$ ) of meat chemical analysis (\% fresh-weight basis) of different treatments' carcasses at the end of the entire experimental period (60 days).

\begin{tabular}{lllll}
\hline Items & $\begin{array}{l}\text { Control } \\
\text { (T1) }\end{array}$ & $\begin{array}{l}\text { Dioxane } \\
\text { (T2) }\end{array}$ & $\begin{array}{l}\text { Dioxane+Vitamin C } \\
\text { (T3) }\end{array}$ & $\begin{array}{l}\text { Vitamin C } \\
\text { (T4) }\end{array}$ \\
\hline Moisture & $75.0 \pm 0.76(1.77)$ & $74.9 \pm 0.84(1.95)$ & $74.2 \pm 1.10(2.57)$ & $75.3 \pm 0.82(1.89)$ \\
Ash & $1.07^{\mathrm{A}} \pm 0.09(14.7)$ & $1.06^{\mathrm{AB}} \pm 0.12(19.6)$ & $0.96^{\mathrm{B}} \pm 0.17(30.1)$ & $0.84^{\mathrm{AB}} \pm 0.14(29.8)$ \\
Crude protein & $22.0 \pm 0.5(3.99)$ & $21.6 \pm 0.58(4.64)$ & $21.7 \pm 0.47(3.77)$ & $22.8 \pm 0.77(5.88)$ \\
Ether extract & $0.25 \pm 0.03(17.4)$ & $0.23 \pm 0.02(15.3)$ & $0.32 \pm 0.06(33.1)$ & $0.25 \pm 0.02(14.0)$ \\
Crude fiber & $2.14^{\mathrm{aA}} \pm 0.07(5.65)$ & $1.38^{\mathrm{bB}} \pm 0.13(16.8)$ & $2.03^{\mathrm{aAB}} \pm 0.07(5.60)$ & $2.23^{\mathrm{aA}} \pm 0.12(9.33)$ \\
\hline *: each value is the mean of 3 rabbits/treatment. A-B and a-b: means in the same row superscripted with different capital or \\
small letters differ significantly at $p \leq 0.01$ or 0.05 , respectively.
\end{tabular}

\section{Discussion}

Similar to dioxane, dioxins and dioxin-like compounds are by-products of various industrial processes, and are commonly regarded as highly toxic compounds that are environmental pollutants and persistent organic pollutants (Pohjanvirta and Tuomisto, 1994). Dioxins and polychlorinated biphenols are chemicals that get into our food from the environment. Foods high in animal fat, such as milk, meat, fish and eggs are the main source of dioxins and PCBs although all foods contains at least low levels of these chemical. Dioxins may be formed as unwanted byproducts in a variety of industrial and combustion processes, including household fires (OEHHA, 2007).

These compounds have also not been shown to have any direct mutagenic or genotoxic activity (Dragan and Schrenk, 2000). Their main action in causing cancer is cancer promotion. A multiphasic dose-response relationship has also been reported, leading to uncertainty and debate about the true role of dioxins in cancer rates. The dioxins toxicity is mediated through the interaction with a specific intracellular protein, the aryl hydrocarbon $(\mathrm{AH})$ receptor, a transcriptional enhancer, affecting a number of other regulatory proteins (Lindén et al., 2010). However, all congeners are not equally important (Van den Berg et al., 2006).
Although the environmental conditions of rearing the experimental rabbits as well as the dietary composition were suitable for the rabbits and the dioxane-dose used herein was very low; yet, dioxane-treated animals reflected some illness symptoms such as weakness, unbalance, nervous, wet-dirty hair of the face, smaller size and weight, weakness of the leg and neck muscles, vertebrates cord malformation (the upper (cervical) part was twisted), more food and water consumption, lower food and economic efficiencies, and lower boneless meat and crude protein percentages comparing with the control groups. Blood analyses revealed that the dietary inclusion of 1,4-dioxane was responsible for occurring a case of multiple anemia [aplastic (toxic), leukemia toxicity, and malnutrition] besides toxic hepatic and biliary tract disease, dehydration, steatorrhea, edema, myocardial infarction and/or excessive protein catabolism. However, vitamin-C inclusion reduced, to some extent, the toxic effect of the dietary dioxaneincluding but not prevented these illness symptoms, since antioxidants are capable of scavenging endogenous reactive oxygen species (ROS). So, antioxidants may be useful in anti-angiogenic therapy to treat various diseases such as cancer (Adams et al., 2004).

However, all groups of dioxin-like compounds are persistent in the environment (Bernes, 1998). So, the 
aforementioned deformity of dioxane-fed rabbit is similar to that happened to the Ukrainian presidential candidate during 2004 (Vuktor Yushchenko) by the revolutionists who used the herbicide 2,4-D against him. Doctors in Vienna confirm diagnosis of Yushchenko's Illness (Police Reopen Case by Elisabeth Rosenthal, Published on 12/12/2004). Since, 2,4-D is still produced by Dow Agroscience and is a common component of over 70 products, including Scott's Weed and Feed, Miracle-Grow Weed and Feed, Weed B Gone and many others (Allen, 2010). Hence 1,4 dioxane may be classified as human carcinogen (EFSA, 2010).

Moreover, dioxane has an $\mathrm{LD}_{50}$ of $5170 \mathrm{mg} / \mathrm{kg}$ (Surprenant, 2000), making it less acutely toxic than table salt $(3000 \mathrm{mg} / \mathrm{kg})$. This compound is irritating to the eyes and respiratory tract. Exposure may cause damage to the central nervous system, liver and kidneys (ICSC, 2006) confirming the obtained results herein in the present study.

Similar results concerning decreased weight gain was confirmed in rats fed 1-4 dioxin. So, PCBs are known to cause health impairments if contaminated foods are eaten over a long period (Anonymous, 2012). Dioxins and PCBs are associated with reduced growth during the peripubertal period and compromise adult body mass, stature, and health (Burns et al., 2010). Even between different mouse and rat strains there may be tenfold to thousand fold differences in acute toxicity (Pohjanvirta and Tuomisto, 1994). Bioconcentration factor (BCF) of dioxane in the range of 0.2-0.7 measured in fish (Franke et al., 1994), suggests BCF in aquatic organisms is low. 1,4-dioxane is very slow to biodegrade having a $0 \%$ BOD and is considered recalcitrant (Kelley et al., 2001).

Dioxane is also classified by the IARC as a Group 2B carcinogen: possibly carcinogenic to humans because it is a known carcinogen in other animals. The U.S. Environmental Protection Agency classifies dioxane as a probable human carcinogen (having observed an increased incidence of cancer in controlled animal studies, but not in epidemiological studies of workers using the compound), and a known irritant (Hazard Summary, 2000). Animal studies in rats suggest that the greatest health risk is associated with inhalation of vapors in the pure form (Kasai et al., 2009).

\section{Conclusion}

Conclusively, 1,4- dioxane is found in different chemicals (cosmetics making foams like liquid soap and shampoo as well as disinfectants and the food additive ethylene glycol) as a contaminant. It is responsible for vertigo, sleepiness, headache, less appetites, skin and eyes irritation, and nervous, depending on the exposed dose and duration to the dioxane.

\section{Conflict of interest statement}

Authors declare that they have no conflict of interest.

\section{References}

Adams, C. D., Scanlan, P. A., Secrist, N. D., 2004. Oxidation and biodegradability enhancement of 1,4-dioxane using hydrogen peroxide and ozone. Environ. Sci. Technol. 28(11), 1812-1818.

Allen, R., 2010. Dioxin War: Truth and Lies about a Perfect Poison. Pluto Press, London.

Anonymous, 2012. PCB und dioxin in eiern: Weiterer fall in niedersachsen. verbraucherzentral ethüringen. http://www. vzth.de/UNIQ133768321807512/dioxin-in-eiern-drei-nrwbetriebe-gesperrt.

AOAC (Association of Official Agricultural Chemists), 1990. Official Methods of Analysis. 15 ${ }^{\text {th }}$ Edn. Published by AOAC, Benjamin Francklin Station, Washington D.C., USA.

Barone, F.S., Rowe, R.K., Quigley, R.M., 1992. A laboratory estimation of diffusion and adsorption coefficients for several volatile organics in a natural clayey soil. J. Contam. Hydrol. 10, 225-250.

Bernes, C., 1998. Persistent organic pollutants. A Swedish View of an International Problem. Swedish Environmental Protection Agency, Monitor 16.

Brown, S. K., Sim, K. R., Abramson, M. J., Gray, C. N., 1994. Concentrations of volatile organic compound in indoor air - A review. Indoor Air. 4, 123-134.

Burns, J. S., Williams, P. L., Sergeyev, O., Korrick, S., Lee, M. M., Revich, B., Altshul, L., Del Prato, J. T., Humblet, O., Jr. Patterson, D. G., Turner, W. E., Needham, L. L., Starovoytov, M., Hauser, R., 2010. Serum dioxins and polychlorinated biphenyls are associated with growth among Russian boys. Pediatrics. 127(1), e59-68.

CAFIA, 2008. Czech Agriculture and Food Inspection Authority: Analyses detected a consignment of guar gum originating from India containing higher levels of pentachlorophenol. http://www.szpi.gov.cz/eng/news /article. asp? id=63053\&cat $=2215 \& \mathrm{ts}=2 \mathrm{ec} 6$.

DeVries, M., Kwakkelz, R. P., Kijlstra, A., 2006. Dioxin in organic eggs - A review. Netherl. J. Agric. Sci. 54, 207-222.

Dragan, Y. P., Schrenk, D., 2000. Animal studies addressing the carcinogenicity of TCDD (or related compounds) with an emphasis on tumour promotion. Food Addit. Contam. 17(4), 289-302.

EFSA, 2010. Results of the monitoring of dioxin levels in food and feed. European Food Safety Authority. http:// www.efsa.europa. eu /en/scdocs/doc/1385. 
Franke, C., Studinger, G., Berger, G., Bohling, M., Bruckamann, U., Cohors-Fresenborg, D., Jöhncke, U., 1994. The assessment of bioaccumulation. Chemosphere. 29, 1501-1514.

Hazard Summary, 2000. 1,4-Dioxane (1,4-Diethyleneoxide). U.S. Environmental Protection Agency. Fact Sheet.

Hong, M.S., Farmayan, W.F., Dortch, I.J., Chiang, C.Y., McMillan, S.K., Schnoor, J.L., Lindén, J., Lensu, S., Tuomisto, J., Pohjanvirta, R., 2010. Dioxins, the aryl hydrocarbon receptor and the central regulation of energy balance-A review. Front. Neuroendocrinol. 31(4), 452-478.

ICSC, 2006. International Chemical Safety Card. National Institute for Occupational Safety and Health.

Kasai, T., Kano, H., Umeda, Y., Sasaki, Ikawa, T. N., Nishizawa, T., Nagano, K., Arito, H., Nagashima, H., Fukushima, S., 2009. Two-year inhalation study of carcinogenicity and chronic toxicity of 1,4-dioxane in male rats. Inhal. Toxicol. 21(11), 889-897.

Kelley, S.L., Aitchison, E.W., Deshpande, M., Schnoor, J.L., Alvarez, P.J.J., 2001. Biodegradation of 1,4-dioxane in planted and unplanted soil: Effect of bioaugmentation with Amycolata sp CB1190. Water Res. 35, 3791-3800.

NDR, 2011. Dioxin-fettekommen von firma ausemde.ndr http://www.ndr.de/regional/niedersachsen/Dioxin101.html

NRC (National Research Council), 2005. Nutrient Requirements of Poultry. National Academy Press. Washington. D. C., USA.

OEHHA, 2007. California Environmental Protection Agency (Cal/EPA).

OPPT, 2014. 1,4-Dioxane Fact Sheet: Support Document. Chemical Fact Sheets. United States Environmental Protection Agency.
Pohjanvirta, R., Tuomisto, J., 1994. Short-term toxicity of 2,3,7,8-tetrachlorodibenzo-p-dioxin in laboratory animals: effects, mechanisms, and animal models. Pharmacol. Rev. 46, 483-549.

Radio Hamburg, 2011. Dioxin in eiern und fleisch.jetztauch in hamburg der dioxin-skandalweitetsichjetztunteranderem auf hamburg und niedersachsenaus. http://www. radiohamburg.de/Hamburg/Nachrichten/2010/Dezember/ Dioxin-in-Eiern-und-Fleisch-Jetzt-auch-in-Hamburg.

Sachs, L., 1976. Statistische Methoden, EinSoforthelfer, Dritte, neubearbeiteteAuflage, Springer- Verlag, Berlin.

Schecter, A., Gasiewicz, T. A. (Eds.), 2004. Dioxins and Health. $2^{\text {nd }}$ Edn. Weiley, New York.

Surprenant, K.S., 2000. Dioxane. In: Ullmann's Encyclopedia of Industrial Chemistry. Wiley-VCH Verlag GmbH \& Co. $\mathrm{KGaA}$.

UKFSA, 2008. UK Food Standards Agency: Update on Irish beef. http://www.food.gov.uk/news/newsarchive/dec/ irishupdate.

Van den Berg, M., Birnbaum, L.S., Denison, M., De Vito, M., Farland, W., Feeley, M., Fiedler, H., Hakansson, H., Hanberg, A., Haws, L., Rose, M., Safe, S., Schrenk, D., Tohyama, C., Tritscher, A., Tuomisto, J., Tysklind, M., Walker, N., Peterson, R.E., 2006. The 2005 World Health Organization reevaluation of human and Mammalian toxic equivalency factors for dioxins and dioxin-like compounds. Toxicol. Sci. 93, 223-241.

Yasuhara, A., Tanaka, Y., Tanabe, A., Kawata, K., Katami, T., 2003. Elution of 1,4-dioxane from waste landfill sites. Bull. Environ. Contam. Toxicol. 71, 641-647.

\section{How to cite this article:}

Abdelhamid, A. M., Ismael, R.F.S.A., Almnsy, M. A., 2016. An attempt to overcome dioxane toxicity by rabbits using vitamin C. Int. J. Curr. Res. Biosci. Plant Biol. 3(5), 33-40.

doi: http://dx.doi.org/10.20546/ijcrbp.2016.305.005 